\title{
Teaching and learning guide for: culture and development of self-regulation
}

\author{
Gisela Trommsdorff \\ University of Konstanz
}

This guide accompanies the following article: Gisela Trommsdorff, 'Culture and Development of Self-Regulation', Social and Personality Psychology Compass 3 (2009): 1-15, doi: 10.1111/j.1751-9004.2009.00209.x

\section{Author's introduction}

Across the lifespan, individuals act to achieve desired goals as agents of their own development. A central means for goal attainment is self-regulation - modifying internal processes and behavior to reach one's goals. Recently, self-regulation has become a topic of intensive research in psychology, with focuses on education, intergroup processes, and consumer behavior. Individuals differ in their preference of goals and also in their ways of reaching these goals. To understand why individuals differ in the ability and motivation to self-regulate, it is key to study the development of self-regulation, taking into account the cultural context.

Most research on the development of self-regulation has been carried out with Anglo-Americans, ignoring differences in standards for self-regulation (behavior and emotion regulation) and related strategies for people from different cultural backgrounds. In line with culture-psychological studies on socialization, it is assumed here that dominant cultural values and related cultural models of agency affect both the socialization conditions of the child and the developmental outcomes of self-regulation. This approach allows for an explanation of cultural and individual differences in self-regulation by linking cultural and individual agency. This article integrates recent research and suggests a cultural model of agency and self-regulation. The proposed model goes beyond individual self-regulation and takes into account interpersonal processes of interdependent self-regulation.

\section{Author recommended references (Descriptions of culture-informed studies are italicized)}

Bandura, A. (2001). Social cognitive theory: An agentic perspective. Annual Review of Psychology, 52, 1-26.

This seminal publication on agency integrates social cognitive and motivational approaches and takes into account the wider sociostructural influences. One feature of human agency is seen in intentionality and self-regulation.

Baumeister, R. F., \& Alquist, J. L. (2009). Self-regulation as a limited resource: Strength model of control and depletion. In J. P. Forgas, R. F. Baumeister \& D. M. Tice (Eds.), Psychology of SelfRegulation: Cognitive, Affective, and Motivational Processes (pp. 21-33). New York: Psychology Press.

This article clarifies the limits of conscious self-regulation. Although benefits of self-regulation (e.g., adjustment, better school grades, and interpersonal success) have been reported in various studies, individuals often fail at self-regulation. Studies using the two-task paradigm show that individuals perform worse on the second task of self-control than on the first task. This indicates that self-regulation is a limited resource.

Blair, C. (2002). School readiness: Integrating cognition and emotion in a neurobiological conceptualization of children's functioning at school entry. American Psychologist, 57, 111-127. 


\section{Social and personality psychology compass: Teaching \& Learning Guide}

This article provides a state-of-the art overview of relevant theorizing and empirical studies on school readiness. It links emotionality, executive function abilities, and academic and social competence to neurobiological approaches to cognitive and emotional development.

Brownell, C. A., \& Kopp, C. B. (2007). Socioemotional Development in the Toddler Years: Transitions and Transformations. New York: Guilford.

The authors bring together influential approaches on social and emotional transitions in the pivotal period of the toddler years. Individual differences in self-control and socioemotional competence are discussed as part of a continuing interplay among other developing systems.

Calkins, S. D., \& Williford, A. P. (2009). Taming the terrible twos: Self-regulation and school readiness. In O. A. Barbarin \& B. H. Wasik (Eds.), Handbook of Early Child Development and Early Education: Research to Practice (pp. 172-198). New York: Guilford.

The authors explain how toddlers will approach new environmental settings such as preschool 'with interest and engagement as opposed to fearfulness and disengagement'. They assume that what is most important for a successful transition is the child's emerging ability to self-regulate for adaptive adjustment and achievement.

Chen, X., Cen, G., Li, D., \& He, Y. (2005). Social functioning and adjustment in Chinese children: The imprint of historical time. Child Development, 76, 182-195.

This study clarifies the impact of sociocultural change on the meaning of self-regulation, social competence, and adjustment in three Chinese cohorts of elementary school children. Shyness was positively associated with social and academic achievement in the 1990 cohort, these associations became weaker in the 1998 cohort and were reversed in the 2002 cohort.

Chen, X., \& French, D. C. (2008). Children's social competence in cultural context. Annual Review of Psychology, 59, 591-616.

This study reviews research on children's social competence and peer relationships in different cultures. The authors show that social initiative and behavior control represent the major dimensions of children's social functioning. An integrative contextual-developmental perspective is presented.

Chen, X., Rubin, K. H., Liu, M., Chen, H., Wang, L., Li, D., et al. (2003). Compliance in Chinese and Canadian toddlers: A cross-cultural study. International Journal of Behavioral Development, 27, 428-436.

This study presents results from a cross-cultural study on the development of a relevant aspect of self-regulation - toddlers' compliance - in China and Canada. Chinese toddlers showed more voluntary committed compliance than did Canadian toddlers, which was positively associated with maternal warmth and induction. Both aspects of parenting and compliance may have different cultural meanings.

Cole, P. M., Bruschi, C. J., \& Tamang, B. L. (2002). Cultural differences in children's emotional reactions to difficult situations. Child Development, 73, 983-996.

This study shows how culture-specific values and socialization influence children's emotional reactions and beliefs about emotion regulation.

Cole, P. M., Martin, S. E., \& Dennis, T. A. (2004). Emotion regulation as a scientific construct: Methodological challenges and directions for child development research. Child Development, 75, 317-333.

This influential study attempts to clarify the concept of emotion regulation and related methodological questions. The authors describe four methods that focus on different aspects of emotion regulation and advance the psychological understanding of this concept. 
Cole, P. M., \& Tan, P. Z. (2007). Emotion socialization from a cultural perspective. In J. E. Grusec \& P. Hastings (Eds.), Handbook of Socialization. Theory and Research (pp. 516-542). New York: Guilford.

This chapter discusses how culture influences emotions, and the socialization of emotions, and the development of emotional competence.

Denham, S. A. (1998). Emotional Development in Young Children. New York: Guilford.

This influential book presents an extensive review of the relevant research as well as several case studies that allow the reader to better understand the emotional experience and the beginning of emotional competence of very young children.

Eisenberg, N., \& Spinrad, T. L. (2004). Emotion-related regulation: Sharpening the definition. Child Development, 75, 334-339.

The authors suggest an alternative and less-encompassing definition of emotion regulation in contrast to the definition put forth by Cole, Martin, and Dennis (2004). They differentiate (a) emotion regulation that originates in other individuals and that stems from the child (inter versus intrapsychic regulation), (b) intentional versus unintentional emotion regulation, and (c) voluntary versus less voluntarily controlled regulation.

Eisenberg, N., Spinrad, T. L., \& Smith, C. L. (2004). Emotion-related regulation: Its conceptualization, relations to social functioning, and socialization. In P. Philippot \& R. S. Feldman (Eds.), The Regulation of Emotion (pp. 277-306). Mahwah, NJ: Erlbaum.

This chapter deals with a conceptual clarification of different types of emotion-related regulation and control. Further, empirical studies on children's socioemotional development and the role of parents' emotion-related socialization are reviewed.

Forgas, J. P., Baumeister, R. F., \& Tice, D. M. (Eds.) (2009). Psychology of Self-Regulation: Cognitive, Affective, and Motivational Processes. New York: Psychology Press.

This edited volume reviews and integrates the most fruitful social-psychological approaches to self-regulation. The chapters provide an overview on recent advances in self-regulation theory and research. The volume goes beyond intrapsychic processes of self-regulation and discusses recent research on self-regulation as fundamental for interpersonal behavior.

Garon, N., Bryson, S. E., \& Smith, I. M. (2008). Executive function in preschoolers: A review using an integrative framework. Psychological Bulletin, 134, 31-60.

Executive function is conceived of as one of the necessary preconditions for the development of self-regulation. This review integrates inconsistent results from studies on preschoolers.

Gross, J. J., \& Thompson, R. A. (2007). Emotion regulation: Conceptual foundations. In J. J. Gross (Ed.), Handbook of Emotion Regulation (pp. 3-24). New York: Guilford.

The authors provide a conceptual outline of emotion regulation that is distinguished from selfregulation and applies to developmental and adult literature. The authors discuss emotions, emotion regulation processes, and emotion regulation strategies.

Holodynski, M., \& Friedlmeier, W. (Eds.) (2006). Development of Emotions and Emotion Regulation. New York: Springer.

This volume deals with theoretical approaches and empirical studies on the development of emotions and emotion regulation, including the authors' own empirical research. The authors are open to a culture-informed perspective. 
Jennings, K. D., Sandberg, I., Kelley, S. A., Valdes, L., Yaggi, K., Abrew, A., et al. (2008). Understanding of self and maternal warmth predict later self-regulation in toddlers. International Journal of Behavioral Development, 32, 108-118.

The authors provide empirical evidence for the role of early understanding of the self (as object and agency) in enabling toddlers to better regulate their behavior.

Karreman, A., van Tuijl, C., van Aken, M. A. G., \& Dekovic, M. (2006). Parenting and selfregulation in preschoolers: A meta-analysis. Infant and Child Development, 15, 561-579.

This meta-analysis of 41 studies deals with the question of relations between parenting and selfregulation in preschoolers. Differences in the strength of these relations are partly attributed to differences in the conceptualizations of self-regulation.

Kochanska, G., \& Thompson, R. A. (1997). The emergence and development of conscience in toddlerhood and early childhood. In J. E. Grusec \& L. Kuczynski (Eds.), Parenting and Children's Internalization of Values: A Handbook of Contemporary Theory (pp. 53-77). Hoboken, NJ: Wiley.

This chapter is a widely cited study on the development of internal regulators of behavior, which are related to the development of conscience in toddlers and early childhood. The authors point out individual differences in conscience development by discussing temperamental individuality and parent-child relationships (attachment) and parental discipline practices.

Kopp, C. B. (1982). Antecedents of self-regulation: A developmental perspective. Developmental Psychology, 18, 199-214.

This widely cited early study gives an overview of the development of self-initiated regulation of behavior from infancy to preschool years. The contribution of cognitive development and the role of caregivers are underlined.

Li, J. (2002). A cultural model of learning: Chinese "heart and mind for wanting to learn". Journal of Cross-Cultural Psychology, 33, 248-269.

This study presents an emic perspective on self-regulation and related emotions based on the Chinese value of life-long learning. This implies a process of moral striving for self-perfection.

Markus, H. R., \& Kitayama, S. (1991). Culture and the self: Implications for cognition, emotion, and motivation. Psychological Review, 98, 224-253.

This influential article discusses the relations among emotions, motivation, self, and behavior from a culture-informed perspective. The authors start from the now classical culture-informed approach differentiating an independent and interdependent self-concept and its relations to motivation and emotions. This study has significant implications for culture-informed developmental studies on self-regulation.

Matsumoto, D. (2001). Culture and emotion. In D. Matsumoto (Ed.), The Handbook of Culture and Psychology (pp. 171-194). New York: Oxford University Press.

The author gives an overview of cross-cultural studies on recognition and judgment of emotion and relates emotions to the understanding of cognition and motivation. He discusses crosscultural studies on the expression, antecedents, appraisal, subjective experience, conceptualization, and physiological correlates of emotions.

McCabe, L. A., Cunnington, M., \& Brooks-Gunn, J. (2004). The development of self-regulation in young children: Individual characteristics and environmental contexts. In R. F. Baumeister \& K. D. Vohs (Eds.), Handbook of Self-Regulation: Research, Theory, and Applications (pp. 340-356). New York: Guilford.

The authors review the development of self-regulation in infants, toddlers, and preschoolers considering environmental and cultural contexts. 
Mikulincer, M., Shaver, P. R., \& Pereg, D. (2003). Attachment theory and affect regulation: The dynamics, development, and cognitive consequences of attachment-related strategies. Motivation E Emotion, 27, 77-102.

This study deals with the different attachment-related strategies of affect regulation, which are seen as resulting from the quality of interactions with significant others. An integrative model of attachment-system activation and dynamics is presented, and the development of attachmentrelated strategies is discussed.

Miller, J. G. (2003). Culture and agency: Implications for psychological theories of motivation and social development. In V. Murphy-Berman \& J. J. Berman (Eds.), Cross-Cultural Differences in Perspectives on the Self (pp. 76-116). Lincoln: University of Nebraska Press.

In this chapter, the author argues for a culture-informed view on the development of agency. Her discussion is closely related to issues of social and emotional development with implications for self-regulation.

Morelli, G. A., \& Rothbaum, F. (2007). Situating the person in relationships: Attachment relationships and self-regulation in young children. In S. Kitayama \& D. Cohen (Eds.), Handbook of Cultural Psychology (pp. 500-527). New York: Guilford.

The authors first review Western-oriented studies on attachment and self-regulation, which view the self as agentic, internally controlled, and relatively stable across contexts. Then, the authors present a culture-informed non-Western view on the self in context and its implications for psychological processes related to attachment and self-regulation. They also focus on the culture-specific developmental conditions for the different notions of the self.

Morling, B., \& Evered, S. (2006). Secondary control reviewed and defined. Psychological Bulletin, 132, 269-296.

The authors discuss a culture-informed theoretical approach to self-regulation by referring to the studies on secondary control. They suggest a 'fit versus control' dimension for a more fruitful review of secondary control research. Fit-focused secondary control is suggested to be more adaptive for coping in interdependent cultural contexts partly, because it may serve the motivation for relatedness.

Porter, C. L., Hart, C. H., Yang, C., Robinson, C. C., Olsen, S. F., Zeng, Q., et al. (2005). A comparative study of child temperament and parenting in Beijing, China and the Western United States. International Journal of Behavioral Development, 29, 541-551.

This study examines linkages between child temperament and parenting styles comparing samples from China and the United States.

Rothbart, M. K., \& Bates, J. E. (2006). Temperament. In W. Damon, R. M. Lerner, \& N. Eisenberg (Eds.), Handbook of Child Psychology. Social, Emotional, and Personality Development (Vol. 3, pp. 99-166). New York: Wiley.

In this influential chapter, an overview on theoretical, empirical, and clinical approaches to the area is presented. A major part of the chapter is devoted to the structure of temperament, as it has emerged from studies in child development and theoretical models of the neurosciences. A section on methods for the study of temperament is included.

Rothbart, M. K., Ellis, L. K., \& Posner, M. I. (2004). Temperament and self-regulation. In R. F. Baumeister \& K. D. Vohs (Eds.), Handbook of Self-Regulation: Research, Theory, and Applications (pp. 357-370). New York: Guilford Press.

This chapter clarifies the role of the relation between reactivity and self-regulation and the implications of effortful control in socioemotional development.

Thompson, R. A. (1994). Emotion regulation: A theme in search of definition. In N. A. Fox (Ed.), The Development of Emotion Regulation: Biological and Behavioural Considerations. Monographs of 
the Society for Research in Child Development (Vol. 59, Issue 2-3, Series 240, pp. 25-52). Chicago, IL: University of Chicago Press.

This influential chapter discusses the concept of emotion regulation and the developmental conditions for emotion regulation and individual differences in emotion regulation skills.

Trommsdorff, G. (2006). Development of emotions as organized by culture. ISSBD Newsletter, 49, $1-4$.

In this article, the author argues for more culture-informed developmental studies in the areas of emotion and emotion regulation.

Trommsdorff, G., \& Cole, P. M. (in press). Emotion, self-regulation, and social behaviour in cultural contexts. In X. Chen \& K. H. Rubin (Eds.), Socioemotional Development in Cultural Context. New York: The Guilford Press.

This chapter gives an overview on relevant research dealing with aspects of self- and emotion regulation from a culture-informed perspective. The developmental conditions and its effects on emotion and social competence in the specific cultural context are discussed in detail.

Trommsdorff, G., \& Friedlmeier, W. (in press). Preschool girls' distress and mothers' sensitivity in Japan and Germany. European Journal of Developmental Psychology.

This study provides evidence for cultural differences in beliefs about emotions and emotion regulation. These affect culture-specific socialization processes (e.g., mothers' sensitivity) such as when children encounter distressing self- or other-focused situations. Results underline universal and culture-specific ways of socializing emotion regulation.

Trommsdorff, G., \& Rothbaum, F. (2008). Development of emotion regulation in cultural context. In S. Ismer, S. Jung, S. Kronast, C. v. Scheve, \& M. Vandekerckhove (Eds.), Regulating Emotions: Social Necessity and Biological Inheritance (pp. 85-120). London: Blackwell.

This chapter integrates culture-informed theoretical approaches and empirical studies on the development of emotion regulation. The authors present several examples of culture-specific socialization conditions for the development of an independent versus interdependent self-construal affecting the cultural meaning of autonomy and relatedness in the process of emotion regulation.

Vohs, K. D., Lasaleta, J. D., \& Fennis, B. (2009). Self-regulation in the interpersonal sphere. In J. P. Forgas, R. F. Baumeister, \& D. M. Tice (Eds.), Psychology of Self-Regulation: Cognitive, Affective, and Motivational Processes (pp. 289-302). New York: Psychology Press.

Although most psychological research on self-regulation has focused on the inner self's role, this chapter goes beyond intrapsychological processes and deals with the influence of self-regulation on interpersonal relations. Starting from the limited resource model approach, the authors ask which interpersonal roles and social behaviors motivate people to exert self-control (and to engage in costly executive functions).

\section{Online materials}

\section{General information: online readings}

Higgins, E. T. (2008). Culture and personality: Variability across universal motives as the missing link. Social and Personality Psychology Compass, 2, 608-634.

Kornadt, H.-J. (2002). Social motives and their development in cultural context. In W. J. Lonner, D. L. Dinnel, S. A. Hayes, \& D. N. Sattler (Eds.), Online Readings in Psychology and Culture 
(Unit 15, Chapter 6). http://www.ac.wwu.edu/ culture/kornadt.htm (Retrieved November 4, 2009).

Lonner, W.J., Dinnel, D. L., Hayes, S. A., \& Sattler, D. N. (Eds.), Online Readings in Psychology and Culture. Retrieved November 4, 2009 from the Western Washington University Center for Cross-Cultural Research Web site: http://www.ac.wwu.edu/ culture/ readings.htm.

Matsumoto, D. (2002). Culture, psychology, and education. In W. J. Lonner, D. L. Dinnel, S. A. Hayes, \& D. N. Sattler (Eds.), Online Readings in Psychology and Culture (Unit 2, Chapter 5). http://www.ac.wwu.edu/ culture/matsumoto.htm (Retrieved 4 November 2009).

Mauss, I. B., Bunge, S. A., \& Gross, J. J. (2007). Automatic emotion regulation. Social and Personality Psychology Compass, 1, 146-167.

Sassenberg, K., \& Woltin, K.-A. (2009). Self-regulation of group members: The case of regulatory focus. Social and Personality Psychology Compass, 3, 118-132.

\section{Sample syllabus: development of self-regulation in cultural context}

\section{Overview}

This seminar is designed to familiarize students with several topics related to self-regulation from a developmental and culture-informed perspective. A major goal is to achieve a better understanding of the psychological processes in the development of self-regulation in different cultural contexts, including the (non-European-American) majority world. The seminar attempts to increase students' knowledge of the course object, focusing primarily on theoretical views and the clarification of concepts and methods for empirical studies. It is intended to encourage critical thinking regarding different theories and empirical studies.

All students are expected to read the required weekly readings plus selected optional publications. Each week, one or two student presenters will prepare oral presentations on research related to the specific week's topic (selected from the reading list and in consultation with the instructor). The presentations are summarized with respect to the weekly topic and open questions to be discussed in the course.

\section{Assessment}

Assessment of successful participation is based on (a) the oral presentation and (b) a thesis (about 10 pages) on a selected topic.

\section{Reading}

Part I. Theoretical approaches to the development of self- and emotion regulation.

Cole, P. M., Martin, S. E., \& Dennis, T. A. (2004). Emotion regulation as a scientific construct: Methodological challenges and directions for child development research. Child Development, 75, 317-333.

Eisenberg, N., \& Spinrad, T. L. (2004). Emotion-related regulation: Sharpening the definition. Child Development, 75, 334-339.

Thompson, R. A. (1994). Emotion regulation: A theme in search of definition. In N. A. Fox (Ed.), The Development Of Emotion Regulation: Biological and Behavioural Considerations. Monographs of the Society for Research in Child Development (Vol. 59, Issue 2-3, Series 240, pp. 25-52). Chicago, IL: University of Chicago Press. 
Part II. Conceptualization: Components of self-regulation and related concepts.

Self-regulation

Baumeister, R. F., \& Vohs, K. D. (2007). Self-regulation, ego depletion, and motivation. Social and Personality Psychology Compass, 1, 115-128.

Karoly, P. (1993). Mechanisms of self-regulation: A systems view. Annual Review of Psychology, 44, 23-52.

Emotion regulation

Mauss, I. B., Bunge, S. A., \& Gross, J. J. (2007). Automatic emotion regulation. Social and Personality Psychology Compass, 1, 146-167.

Behavior regulation

Metcalfe, J., \& Mischel, W. (1999). A hot/cool-system analysis of delay of gratification: Dynamics of willpower. Psychological Review, 106, 3-19.

Inhibitory control and executive skills

Kochanska, G., Murray, K., Jacques, T. Y., Koenig, A. L., \& Vandegeest, A. (1996). Inhibitory control in young children and its role in emerging internalization. Child Development, 67, 490507.

Oh, S., \& Lewis, C. (2008). Korean preschoolers' advanced inhibitory control and its relation to other executive skills and mental state understanding. Child Development, 79, 80-99.

Part III. Individual differences in self-regulation and socioemotional development.

\section{Temperament}

Chen, X., Wang, L., \& DeSouza, A. (2006). Temperament, socioemotional functioning, and peer relationships in Chinese and North American children. In D. C. French \& B. H. Schneider (Eds.), Peer Relationships in Cultural Context (pp. 123-147). New York: Cambridge University Press.

Fox, N. A., \& Calkins, S. D. (1993). Pathways to aggression and social withdrawal: Interactions among temperament, attachment, and regulation. In K. H. Rubin \& J. B. Asendorpf (Eds.), Social Withdrawal, Inhibition, and Shyness in Childhood (pp. 81-100). Hillsdale, NJ: Erlbaum.

Rothbart, M. K., Ellis, L. K., \& Posner, M. I. (2004). Temperament and self-regulation. In R. F. Baumeister \& K. D. Vohs (Eds.), Handbook of Self-Regulation: Research, Theory, and Applications (pp. 357-370). New York: Guilford Press.

\section{Internalization}

Chen, X., Rubin, K. H., Liu, M., Chen, H., Wang, L., Li, D., et al. (2003). Compliance in Chinese and Canadian toddlers: A cross-cultural study. International Journal of Behavioral Development, 27, 428-436.

Laible, D. J., \& Thompson, R. A. (2000). Mother-child discourse, attachment security, shared positive affect, and early conscience development. Child Development, 71, 1424-1440.

Miller, J. G. (2003). Culture and agency: Implications for psychological theories of motivation and social development. In V. Murphy-Berman \& J. J. Berman (Eds.), Cross-Cultural Differences in Perspectives on the Self (pp. 76-116). Lincoln: University of Nebraska Press.

Development of self- and emotion regulation and social competence

Karreman, A., van Tuijl, C., van Aken, M. A. G., \& Dekovic, M. (2006). Parenting and selfregulation in preschoolers: A meta-analysis. Infant and Child Development, 15, 561-579.

Ryan, R. M., \& Deci, E. L. (2000). Self-determination theory and the facilitation of intrinsic motivation, social development, and well-being. American Psychologist, 55, 68-78. 
Spinrad, T. L., Eisenberg, N., Cumberland, A., Fabes, R. A., Valiente, C., Shepard, S. A., et al. (2006). Relation of emotion-related regulation to children's social competence: A longitudinal study. Emotion, 6, 498-510.

Spinrad, T. L., Eisenberg, N., Gaertner, B., Popp, T., Smith, C. L., Kupfer, A., et al. (2007). Relations of maternal socialization and toddlers' effortful control to children's adjustment and social competence. Developmental Psychology, 43, 1170-1186.

\section{Part IV. Development of self-regulation in cultural context.}

Culture, self-construal, motivation, and emotions

Kitayama, S., Mesquita, B., \& Karasawa, M. (2006). Cultural affordances and emotional experience: Socially engaging and disengaging emotions in Japan and the United States. Journal of Personality and Social Psychology, 91, 890-903.

Markus, H. R., \& Kitayama, S. (1991). Culture and the self: Implications for cognition, emotion, and motivation. Psychological Review, 98, 224-253.

Markus, H. R., \& Kitayama, S. (1994). The cultural construction of self and emotion: Implications for social behavior. In S. Kitayama \& H. R. Markus (Eds.), Emotion and Culture: Empirical Studies of Mutual Influence (pp. 89-130). Washington, DC: American Psychological Association.

Morling, B., \& Kitayama, S. (2008). Culture and motivation. In J. V. Shah \& W. L. Gardner (Eds.), Handbook of Motivation Science (pp. 417-433). New York: Guilford.

\section{Culture and attachment}

Morelli, G. A., \& Rothbaum, F. (2007). Situating the person in relationships: Attachment relationships and self-regulation in young children. In S. Kitayama \& D. Cohen (Eds.), Handbook of Cultural Psychology (pp. 500-527). New York: Guilford.

Rothbaum, F., Nagaoka, R., \& Ponte, I. C. (2006). Caregiver sensitivity in cultural context: Japanese and U.S. teachers' beliefs about anticipating and responding to children's needs. Journal of Research in Childhood Education, 21, 23-40.

\section{Culture and self-regulation}

Morelli, G. A., \& Rothbaum, F. (2007). Situating the person in relationships: Attachment relationships and self-regulation in young children. In S. Kitayama \& D. Cohen (Eds.), Handbook of Cultural Psychology (pp. 500-527). New York: Guilford.

Morling, B., \& Evered, S. (2006). Secondary control reviewed and defined. Psychological Bulletin, 132, 269-296.

Rothbaum, F., Weisz, J. R., \& Snyder, S. S. (1982). Changing the world and changing the self: A two-process model of perceived control. Journal of Personality and Social Psychology, 42, $5-37$.

Trommsdorff, G., \& Cole, P. M. (in press). Emotion, self-regulation, and social behaviour in cultural contexts. In X. Chen \& K. H. Rubin (Eds.), Socioemotional Development in Cultural Context. New York: Guilford.

Culture and parenting

Grusec, J. E., \& Goodnow, J. J. (1994). Impact of parental discipline methods on the child's internalization of values: A reconceptualization of current points of view. Developmental Psychology, 30, 4-19.

Rothbaum, F., \& Trommsdorff, G. (2007). Do roots and wings oppose or complement one another? The socialization of autonomy and relatedness in cultural context. In J. E. Grusec \& P. Hastings (Eds.), The Handbook of Socialization (pp. 461-489). New York: Guilford. 
Trommsdorff, G., \& Kornadt, H.-J. (2003). Parent-child relations in cross-cultural perspective. In L. Kuczynski (Ed.), Handbook of Dynamics in Parent-Child Relations (pp. 271-306). Thousand Oaks, CA: Sage.

Trommsdorff, G., \& Rothbaum, F. (2008). Development of emotion regulation in cultural context. In S. Ismer, S. Jung, S. Kronast, C. v. Scheve, \& M. Vandekerckhove (Eds.), Regulating Emotions: Social Necessity and Biological Inheritance (pp. 85-120). London: Blackwell.

Culture and socialization of emotions

Cole, P. M., \& Tamang, B. L. (1998). Nepali children's ideas about emotional displays in hypothetical challenges. Developmental Psychology, 34, 640-646.

Cole, P. M., Tamang, B. L., \& Shrestha, S. (2006). Cultural variations in the socialization of young children's anger and shame. Child Development, 77, 1237-1251.

Cole, P. M., Walker, A. R., \& Lama-Tamang, M. S. (2006). Emotional aspects of peer relations among children in Rural Nepal. In X. Chen, D. C. French, \& B. H. Schneider (Eds.), Peer Relationships in Cultural Context (pp. 148-169). New York: Cambridge University Press.

Trommsdorff, G. (2006). Development of emotions as organized by culture. ISSBD Newsletter, 49, $1-4$.

Culture, emotion regulation, and social behavior

Friedlmeier, W., \& Trommsdorff, G. (1999). Emotion regulation in early childhood: A crosscultural comparison between German and Japanese toddlers. Journal of Cross-Cultural Psychology, 30, 684-711.

Li, J. (2002). A cultural model of learning: Chinese "heart and mind for wanting to learn". Journal of Cross-Cultural Psychology, 33, 248-269.

Trommsdorff, G., \& Friedlmeier, W. (in press). Preschool girls' distress and mothers' sensitivity in Japan and Germany. European Journal of Developmental Psychology.

Trommsdorff, G., Friedlmeier, W., \& Mayer, B. (2007). Sympathy, distress, and prosocial behavior of preschool children in four cultures. International Journal of Behavioral Development, 31, 284-293.

\section{Focus questions}

On the development of self-regulation in cultural context

1. How has the study of culture influenced theories on and knowledge of the development of self-regulation?

2. Do studies on self-regulation profit from a culture-informed approach? In what way?

3. Should the improvement of self-regulation be a goal in education? In what way?

4. Does education for self-regulation base on universal- or culture-specific strategies?

5. Comment on applied aspects and give examples for each situation: How does selfregulation function in:

- interpersonal communication

- learning situations

- achievement situations

- the family (parent-child interactions)

- the school context

- and at the work place? 


\section{Project/demonstration ideas (for instructor)}

1. Present a scenario to all students: children from different cultures (e.g., Japan, USA) experience frustration after failing in an achievement task. Ask students to take the role of a parent or teacher and describe (a) how they would tell the children (from culture A and from culture B) to react and (b) why they would tell the children to react this way.

2. Present a scenario to all students: children from different cultures (e.g., Japan, USA) observe another person in distress. Ask students (a) what kinds of reactions they would expect from the children (emotional and behavioral), and (b) how they would react to the children if they were the child's parent or teacher.

3. Ask students to give examples of successful and unsuccessful self-regulation from their own experience, and how they would try to improve self-regulation (a) in an achievement situation and (b) in a conflict situation with peers.

4. Ask students (a) to rate themselves, (b) to rate a person they do not like, and (c) to rate a person from another culture (e.g., Japan, USA) on aspects of self-regulation:

- regulation of negative and positive emotions (specify the kind of emotion);

- behavior regulation (e.g., delay of gratification)

5. Ask students (a) whether and why they believe that children should learn open expression and communication of emotion (and which emotions) or suppression of emotion (and which emotions), and (b) whether and why they believe that individuals from independent and interdependent cultural models should learn different modes of emotional expression.

6. Ask students (a) whether self-regulation is relevant for interpersonal behavior (benefits and costs), and whether this is different in different cultures (e.g., Japan, USA), and (b) how self-regulation comes into play when interacting with persons from another culture.

7. Ask students:

- How might culture and socialization influence a child's self-regulation?

- How may specific child-rearing practices in a certain culture influence the child's self-regulation and social competence?

\section{References}

Selection of basic references

Cole, P. M., Martin, S. E., \& Dennis, T. A. (2004). Emotion regulation as a scientific construct: Methodological challenges and directions for child development research. Child Development, 75, 317-333.

Eisenberg, N., \& Spinrad, T. L. (2004). Emotion-related regulation: Sharpening the definition. Child Development, 75, 334-339.

Karoly, P. (1993). Mechanisms of self-regulation: A systems view. Annual Review of Psychology, 44, 23-52.

Karreman, A., van Tuijl, C., van Aken, M. A. G., \& Dekovic, M. (2006). Parenting and selfregulation in preschoolers: A meta-analysis. Infant and Child Development, 15, 561-579.

Morling, B., \& Evered, S. (2006). Secondary control reviewed and defined. Psychological Bulletin, 132, 269-296. 
Rothbaum, F., \& Trommsdorff, G. (2007). Do roots and wings oppose or complement one another? The socialization of autonomy and relatedness in cultural context. In J. E. Grusec \& P. Hastings (Eds.), The Handbook of Socialization (pp. 461-489). New York: The Guilford Press.

Trommsdorff, G., \& Cole, P. M. (in press). Emotion, self-regulation, and social behaviour in cultural contexts. In X. Chen \& K. H. Rubin (Eds.), Socioemotional Development in Cultural Context. New York: Guilford.

\section{Acknowledgment}

This research was financed by a grant from the German Research Foundation (DFG GZ, TR 169/14-2). I am grateful to Holly Bunje for her editing. 